\title{
Kajian Analisi Hubungan Kondisi Fisik Rumah Resiko Peceraian Terhadap Penderita TB Paru Di Rungan Perawatan TB Paru Rsud Arifin Achmad Pekanbaru
}

\author{
Chairil, \\ chairil@umri.ac.id
}

\begin{abstract}
Pulmonary tuberculosis (pulmonary tuberculosis) is the third cause of death after cardiovascular and respiratory tract diseases. The factors that cause pulmonary tuberculosis include low income, economically low nutritional quality of the community, poor physical condition of the house (including air quality in the house), as well as the risk of divorce from pulmonary tuberculosis patients. This study aims to determine the relationship of physical risk conditions of the house. Pulmonary TB patients Population and sample of this study 80 respondents in June 3 to August 2018 with the sample ascentental method. As a result of this study there is a relationship between the physical condition of the house with Pulmonary TB that there is a significant relationship between Physical House with Patients with Pulmonary TB. This is evidenced by the value of $\mathrm{P}$ - value> 0.05 which is 1.120 with OR: 0.346 and $85 \%$ CI: $0.075-1.409$. And for the risk of divorce with pulmonary tuberculosis there is no meaningful relationship between divorce and patients with pulmonary TB. This is evidenced by the $\mathrm{P}$ value - value $>0.05$ which is 0.120 with OR: 0.326 and $95 \%$ CI: 0.075 - 1.409. Conclusion This paper is a physical home code such as occupancy density, ventilation and kitchen room temperature can be the occurrence of pulmonary $\mathrm{Tb}$ so recommended to improve the condition of the house and treatment of patients as early as possible until the patient is cured and for the risk of divorce there is no relationship with pulmonary tuberculosis the couple accept the state of being, but the need for promotional measures to provide a picture of a healthy home condition and divorce is not a solution

for

TB

sufferers
\end{abstract}

Lungs.

Keywords : pulmonary tuberculosis, state of the home condition, risk of divorce

\begin{abstract}
ABSTRAK
Penyakit tuberkulosis paru (Tb paru) merupakan penyakit penyebab kematian ketiga setelah penyakit kardiovaskuler dan saluran pernafasan. Faktor-faktor penyebab tuberkulosis paru antara lain rendahnya pendapatan, secara ekonomi kualitas gizi masyarakat rendah, buruknya kondis fisik rumah (termasuk kualitas udara dalam rumah), Serta resiko peceraian dari penderita Tb Paru Penelitian ini bertujuan untuk mengetahui hubungan Kondisi resiko fisik rumah Resiko penceraian terhadap penderita Tb paru Populasi dan sampel penelitian ini 80 responden dalam 3 bulan juni sampai agustus 2018 dengan metode asedental sampel.hasil dari penelitian ini terdapat hubungan kondisi fisik rumah dengan Tb Paru bahwa terdapat hubungan yang bermakna antara Fisik rumah dengan Penderita TB Paru. Hal tersebut dibuktikan dengan nilai P - value $>0,05$ yaitu 1,120 dengan OR: 0,346 dan CI 85\% : 0,075 - 1,409. Dan untuk Resiko peceraian dengan Tb Paru tidak terdapat hubungan yang bermakna antara peceraian dengan Penderita TB Paru. Hal
\end{abstract}


tersebut dibuktikan dengan nilai P - value >0,05 yaitu 0,120 dengan OR: 0,326 dan CI 95\% : 0,075 1,409.Kesimpulan tulisan ini yaitu kodis fisik rumah seperti kepadatan hunian, ventilasi dan suhu ruangan dapur dapat sebagai terjadinya $\mathrm{Tb}$ paru sehingga disarankan untuk memperbaiki kondisi rumah dan pengobatan penderita sedini mungkin hingga penderita sembuh dan untuk resiko terjadinya peceraian tidak ada hubungan dengan $\mathrm{Tb}$ paru pasangan menerima keadaan apa adanya akan tetapi perlu adanya tindakan promos untuk dapat memberikan gambaran kondisi rumah yang sehat serta peceraian bukanlah satu solusi dari penderita TB Paru.

\section{Kata Kunci: Tb paru, keadaan kondisi rumah,resiko peceraian}

\section{PENDAHULUAN}

Tuberkulosis ( $\mathrm{Tb})$ paru merupakan penyakit infeksi kronik dan menular yang erat kaitannya dengan keadaan lingkungan dan perilaku masyarakat. Penyakit ini merupakan penyakit infeksi yang disebabkan oleh Mycobacterium tuberculosis. Penyakit ini ditularkan melalui udara yaitu lewat percikan ludah, bersin dan batuk. Penyakit Tb paru biasanya menyerang paru dan dapat pula menyerang organ tubuh yang lain. Tb paru masih menjadi masalah kesehatan di dunia. Penyakit Tb paru banyak menyerang kelompok usia produktif dan kebanyakan berasal dari kelompok sosial ekonomi rendah dan tingkat pendidikan yang rendah (Aditama, 2002).

Adanya fenomena peningkatan insidensi dan prevalensi kasus $\mathrm{Tb}$ paru di seluruh dunia, yang dikenal sebagai fenomena Tb paru global, telah mendorong WHO mendeklarasikan global health emergency pada bulan maret 1993, untuk menyadarkan masyarakat dunia bahwa kita sedang menghadapi ancaman serius penyakit Tb paru. Pada bulan September 2000, diselenggarakan Konferensi Tingkat Tinggi (KTT) Perserikatan Bangsa-Bangsa (PBB) yang diikuti oleh 189 negara anggota. Konferensi itu menyepakati untuk mengadopsi Tujuan Pembangunan Milenium atau Millenium Development Goals (MDGs).

Tantangan untuk memenuhi delapan tujuan diatas tersebut memiliki keterkaitan satu dengan yang lainnya. Tercapainya satu tujuan, dapat mendekatkan pencapaian tujuan lainnya. Berdasarkan hal tersebut maka penurunan jumlah kasus insidensi dan prevalensi penyakit Tb menjadi salah satu tujuan MDGs yang mesti secara bersama-sama diperjuangkan hingga tahun 2015 (Anonim, 2008).

Hasil Riset Kesehatan Dasar (RISKESDAS) tahun 2013 menunjukkan Prevalensi penduduk Indonesia yang didiagnosis TB paru oleh tenaga kesehatan adalah 0.4 persen. Lima provinsi dengan TB paru tertinggi adalah Jawa Barat (0.7\%), Papua (0.6\%), DKI Jakarta (0.6\%), Gorontalo (0.5\%), Banten (0.4\%) dan Papua Barat (0.4\%). (Badan Penelitian dan Pengembangan Kesehatan. Riset Kesehatan Dasar (Riskesdas) 2010. Jakarta: Kementerian Kesehatan Republik Indonesia; 2010). Dengan keadaan rumah yang kurang pencayaan dan vitilasi resiko penyebaran bakteri ke orang lain di tambah dengan kurang mendapat dukungan dari keluarga maupun temannya lebih menjauh disebabkan karena penyakit yang dideritanya. Mereka telah menyadari bahwa TB paru mudah sekali menular, sehingga terjadinya resiko perceraian. dimana orang-orang sekitar penderita sengaja membatasi kontak dengan penderita, karena takut tertular. termasuk istri maupun anak-anaknya. (Achmad Hudoyo ,2017)

RSUD Arifin Achmad Propinsi Riau merupakan Rumah Sakit rujukan dari beberapa Rumah Sakit yang berada di dalam maupun di luar Propinsi Riau. Menurut data dari Medical Record RSUD Arifin Achmad pada tahun 2013 kasus TB paru mencapai 180 jiwa dan pada tahun 2014 kasus TB paru mencapai 107 jiwa. 
Sedangkan pasien TB yang putus minum obat pada tahun 2013 berjumlah 30 orang (16,67 \%), sedangkan tahun 2014 sebanyak 43 orang (40,18\%). Observasi yang di lakukan di rungan perawatan penyakit paru pasien yang menderita $\mathrm{Tb}$ paru yang di kunjungi oleh keluarganya terutama istri atau suami dari 10 responden 3 responden yang mendampingi 7 tidak mendapingi surve ini bersifar eksidendal dari hal peneliti ingin mengetahui apa penderita TB paru beresiko untuk di tinggalkan pasangannya.Temuan penelitian menunjukkan bahwa sebagian besar informan penelitian kurang memahami makna dan tujuan perkawinan. Berbagai hal yang dikemukakan sebagai penyebab perceraian, seperti ekonomi, kekerasan dalam rumah tangga (KDRT), perselingkuhan, dan sebagainya, sejatinya hanya merupakan pemicu, namun yang paling mendasar sebagai penyebab perceraian adalah tidak adanya komitmen antar masing-masing pasangan dalam mencapai tujuan perkawinan (Prianto,2013)

\section{METODOLOGI PENELITIAN}

Penelitian mengunakan metode survai analitik dengan pendekatan cross sectional yaitu mempelajari di namika kolerasi antara kondisi fisik rumah meliputi ventelasi ,pencahayaan, dan dapur dan resiko penceraian terhadap TB Paru Kegiatan penelitian ini di ruangan perawatan TB Paru RSUD arifin ahmad Pekanbaru di laku/Juni sampai dengan Angustus 2018 dengan 40 Responden yang menderita Tb paru di ruangan perawatan penelitian Alat yang di gunakan untuk membantu pengumpulan data adalah kusioner ,alat tulis tape recorder ,HP dan peneliti sendiri yang akan melakukan wawancara langsung pada responden.

Data yang di peroleh di masukan ke dalam program pengolahan data dengan mengunakan komputer data dianalisa dengan mengunakan dua cara yaitu analisa univariat dan bivariate Analisa bivariat di alakukan untuk mengetahui hubungan antara variabel dependen dengan variabel independen dengan mengunakan komputer dengan uji statist Chi sguare dengan alfa sama dengan 0,05 dari uji ini di peroleh nilai $p$ value bila kurang dari 0,05 terdapat adanya hubungan dan bila besar dari 0,05 tidak ada hubungan.

\section{HASIL DAN PEMBAHASAN}

Berdasarkan pengambilan data yang dilakukan pada tanggal bulan juni sampai Agustus 2018 di RSUD Pekanbaru, dari 40 responden dapat diperoleh data sebagai berikut

a.Analisa Univariat

Tabel 1. Distribusi Frekuensi Umur di Rungan Poli Paru terpadu Juni-Agustus 2018

\begin{tabular}{|c|c|c|c|}
\hline No & $\begin{array}{l}\text { Ketagori Umur } \\
\text { (Tahun) }\end{array}$ & $\begin{array}{l}\text { Frekuensi } \\
\text { (f) }\end{array}$ & $\begin{array}{c}\text { Persentase } \\
\text { (\%) }\end{array}$ \\
\hline 1 & Dewasa Akhir (36-45) & 20 & 50 \\
\hline 2 & Lansia Awal (46-55) & 12 & 30 \\
\hline 3 & Lansia Akhir (56-65) & 8 & 20 \\
\hline & Total & 40 & 100 \\
\hline
\end{tabular}

Berdasarkan tabel 1 dapat diketahui bahwa umur berumur dewasa akhir 36 - 45 tahun yaitu sebanyak 20 responden $(50,0 \%)$. 
Tabel 2. Distribusi Frekuensi Umur di Rungan Poli Paru Perpadu Juni - Agustus 2018

\begin{tabular}{llcc}
\hline No & Jenis Kelamin & Frekuensi (f) & Persentase (\%) \\
\hline $\mathbf{1}$ & Laki - laki & 14 & 35 \\
$\mathbf{2}$ & Perempuan & 26 & 65 \\
& Total & 40 & 100 \\
\hline
\end{tabular}

Berdasarkan tabel 2 diperoleh hasil bahwa frekuesi jenis kelamin mayoritasberjenis kelamin perempuan dengan 26 responden $(65 \%)$.

Tabel 3. Distribusi Frekuensi Pendidikan di Rungan Poli Paru Perpadu Juni - Agustus 2017

\begin{tabular}{llll}
\hline No & Jenis Pendidikan & $\begin{array}{c}\text { Frekuensi } \\
\text { (f) }\end{array}$ & $\begin{array}{c}\text { Persentase } \\
(\%)\end{array}$ \\
\hline $\mathbf{1}$ & Sarjana & 2 & 5 \\
2 & SLTA & 20 & 50 \\
3 & SLTP & 8 & 20 \\
$\mathbf{4}$ & SD & 10 & 25 \\
& & & \\
& Total & 40 & 100 \\
\hline
\end{tabular}

Berdasarkan tabel 3 diperoleh data pendidikan mayoritas pendidikannya adalah SLTA sebanyak 20 responden (50\%).

Tabel 4. Distribusi Frekuensi Pekerjaan di Rungan Poli Paru Perpadu Juni-Agustus 2017

\begin{tabular}{llcc}
\hline No & Jenis Pekerjaan & $\begin{array}{c}\text { Frekuensi } \\
(\mathbf{f})\end{array}$ & $\begin{array}{c}\text { Persentase } \\
(\%)\end{array}$ \\
& & & \\
& & & \\
$\mathbf{1}$ & Pensiunan & 7 & 17,5 \\
2 & Wiraswasta & 13 & 32,5 \\
3 & IRT & 5 & 12,5 \\
$\mathbf{4}$ & Swasta & 15 & 37,5 \\
& & & \\
& & & 100 \\
\hline
\end{tabular}

Berdasarkan tabel 4 diperoleh data jenis pekerjaan adalah swata sebanyak 15 responden (37,5\%). 


\section{b.Analisis Bivariat}

\section{Hubungan Kodisi rumah dengan Tb Paru}

Hubungan antara faktor kondisi rumah dengan $\mathrm{Tb}$ paru yang meliput; ventelasi, pencayahaan dan dapur/ WC dengan Tb paru dapat dilihat pada tabel 5.

\section{Tabel 5. Distribusi Kondisi rumah dengan Tb paru di di Rungan Poli Paru Perpadu Juni - Agustus} 2017

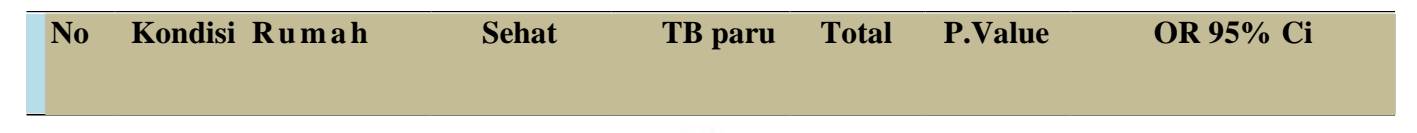

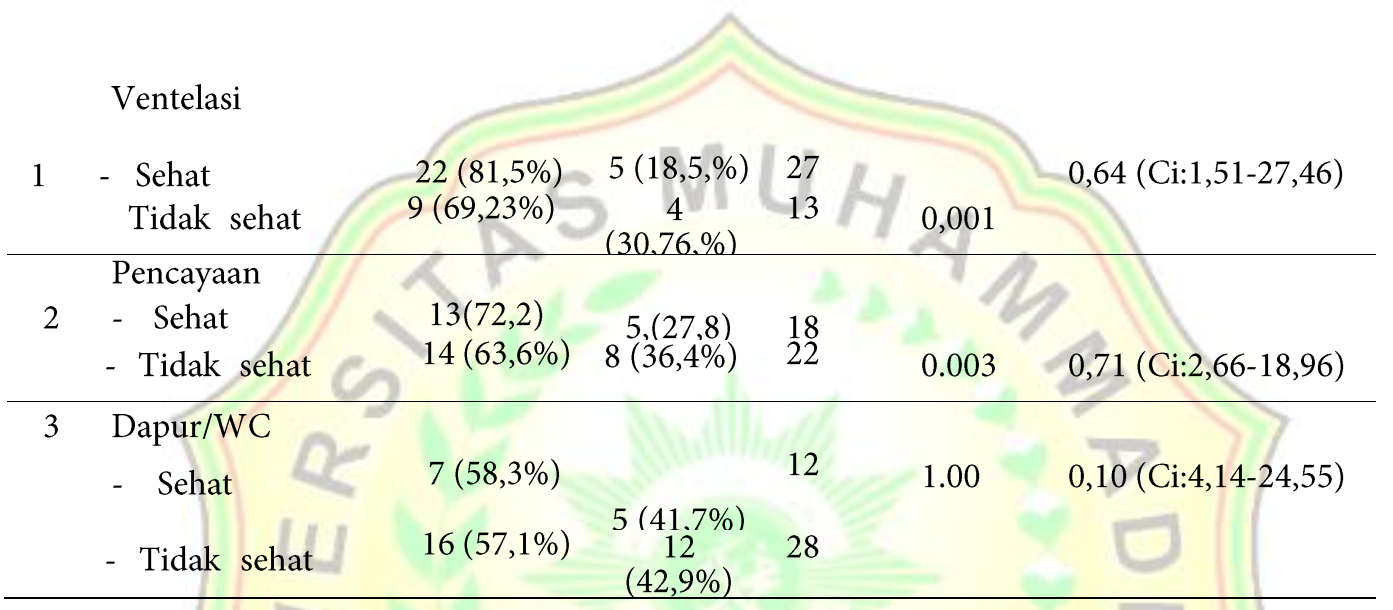

Berdasarkan tabel 5 dapat dilihat bahwa,untuk,ventelasi ada hubungan dengan $\mathrm{Tb}$ paru , karena dari hasil uji statistik chi-square dengan continuity correction diperoleh nilai $\mathrm{p}=(0,001)<\alpha=(0,05)$ dengan demikian $\mathrm{p}$-value lebih kecil dari alpha, berarti ada perbedaan yang bermankna Tb paru dengan kondisi rumah yang sehat maupun yang tidak sehat, namun secara presentase responden pada distribusi ventelasi tidak sehat $9,(69,23 \%)$ dan terkena Tb paru $4,(30,76 \%)$. Pada hasil diatas OR yaitu $0,64(95 \%$ Ci:1,51-27,46), ini berarti kondisi ventelasi tidak sehat mempunyai peluang 0,64 untuk terkena Tb paru dibandingkan dengan kondisi ventelasi sehat. Tuberkulosis paru ( $\mathrm{Tb}$ paru) merupakan suatu penyakit infeksi yang disebabkan oleh bakteri Mycobacterium tuberculosis. Bakteri ini berbentuk batang dan bersifat tahan asam sehingga dikenal juga sebagai Basil Tahan Asam (BTA). Sebagian besar kuman Tb menyerang paru, tetapi dapat juga menyerang organ tubuh lain. kuman $\mathrm{Tb}$ cepat mati dengan sinar matahari langsung, tetapi dapat bertahan hidup beberapa jam di tempat yang gelap dan lembab. Dalam jaringan tubuh, kuman ini dapat dormant, tertidur lama selama beberapa tahun (Anonim, 2002). Peneliti berpendapat dari hasil di atas dapat ketahui keadaan responden di runagna $\mathrm{Tb}$ paru terpadu mayoritas responden pekerjaan swasta 15 atau 37,5 \% berumur antara 36-45 berjumlah 20 orang atau 50, \% hal ini bila dikolerasikan peran berkerja di luar dan swsta sering terpapar di luar Faktor lain yang menyebabkan ada hubungan antara keadaan ventelasi dengan $\mathrm{Tb}$ paru mungkin disebabkan keadaan ventelasi yang tidak memenuhi standar atau kurang dari yang semetinya atau kecil ( lobang-Lobang) ventilasi adalah $15 \%$ dari luas lantai, karena ventilasi mempunyai fungsi nya sebagai serkulasi udara (Azwar, 1999). Selanjutnya penelitian yang dilakukan Sumarjo (2004) di Kabupaten Banjarnegara 
memperoleh hasil yaitu adanya hubungan antara ventilasi rumah dengan kejadian $\mathrm{Tb}$ paru dengan nilai p sebesar 0,003 dan $\mathrm{OR}=6,176$. Hal ini berarti individu yang tinggal di rumah dengan luas ventilasi yang tidak memenuhi syarat memiliki risiko terkena Tb paru sebesar 6,2 kali dibandingkan mereka yang memiliki luas ventilasi yang memenuhi syarat. Selanjutnya, Tobing (2009) menyatakan bahwa dalam penelitian yang dilakukannya diperoleh hasil yatu nilai p sebesar 0,037 dan nilai OR sebesar 2,4 (9\% CI1,04-5.8). Selanjutnya, Darsoni (2005) yang melaksanaan penelitian di Desa Padang memperoleh hasil yaitu bahwa adanya hubungan antara luas ventilasi rumah dengan kejadian Tb paru dimana nilai $\mathrm{p}=$ 0,001 dan OR sebesar 10,8.

Pencayaan ada hubungan dengan Tb Paru, karena dari hasil uji statistik chi-square dengan continuity correction diperoleh nilai $\mathrm{p}=(0,003)<\alpha(0,05)$, dengan demikian $\mathrm{p}$ - value lebih kecil dari alpha , berarti ada berpedaan yang bermakna terkena Tb paru dengan pencayaan yang sehat maupun yang tidak sehat, namun secara presentase responden pada distribusi keadaan pencayaan tidak sehat 14 (63,6\%) dan terkena Tb paru 8 (36,4\%). Pada hasil diatas Pada hasil diatas OR yaitu 0,71 (95\% Ci:2,66$18,96)$, ini berarti pencayahann yang tidak sehat mempunyai peluang 0,71 untuk terkena $\mathrm{Tb}$ paru dibandingkan dengan kondisi ventelasi sehat. Peneliti berpendapat dari hasil di atas dapat ketahui keadaan adanya hubungan antara pencahaya dengan $\mathrm{Tb}$ paru dimana pencahayaan yang sehat memberikan kontribusi pada Suhu udara yang ideal dalam rumah antara $18-30^{\circ} \mathrm{C}$. Suhu optimal pertumbuhan bakteri sangat bervariasi. Mycobacterium tuberculosis tumbuh optimal pada suhu $37^{\circ} \mathrm{C}$. Paparan sinar matahari selama 5 menit dapat membunuh M. tuberculosis dan tahan hidup pada tempat gelap, sehingga perkembangbiakan bakteri lebih banyak di rumah yang gelap (Anonim, 1999). Beberapa penelitian telah dilakukan yang menegaskan bahwa suhu udara bisa menjadi salah satu faktor penyebab (faktor risiko) Tb paru seperti penelitian yang dilakukan oleh Fatimah (2008) yang menyatakan bahwa ada hubungan antara kejadian Tb paru dengan suhu (OR 2,674). Selanjutnya, Atmosukarto dan Soewasti (2000) yang melakukan penelitian tentang pengaruh lingkungan permukiman dengan kejadian Tb paru menemukan bahwa suhu ruangan memberikan pengaruh terhadap kejadiaan $\mathrm{Tb}$ paru dengan OR sebesar 5,126. Hal ini menunjukkan bahwa individu yang memiliki rumah dengan suhu $\langle 18 /\rangle$ $30^{\circ} \mathrm{C}$ memiliki risiko terkena Tb paru sebesar 2,7 an 5,1 kali dibandingkan dengan suhu ruangan 18-30. Terkena Tb Paru dengan dapur /WC yang sehat maupun yang tidak sehat.Namun secara presentase responden pada distribusi dapur / WC tidak sehat 7(58,3\%) dan terkena Tb paru 5 (18,5\%) Pada hasil diatas OR yaitu 0,64 (95\% Ci:2,66-18,96), ini berarti dapur/limbah WC yang tidak sehat mempunyai peluang 0,64 untuk terkena diare dibandingkan dengan kondisi pembuangan limbah WC sehat. Peneliti berpendapat dari hasil di atas dapat ketahui keadaan responden di tidak adanya hubungan antara dapur/ Pembuangan limbah WC dengan Tb paru ini keberadaan WC responden mengunakan model septic tankPengunaan WC model septic tank menenuhui standar kesehatan, dimana keberadaan tertutup, tidak mencemari lingkungan di sekitar, tidak berbau, (Notoatmodjo. 2002). Hanya saja keberadaan dapur/WC masih dalam satu rungan dan untuk keberadaan Wc ada yang berbau ada yang tidak berbau ini disebabkan kurangnya peratian untuk membersihkan.Pengunaan jamban model septic tank merupakan sesuatu program yang dianjurkan oleh pemerinta di kenal dengan jamban sehat, ini jelas tidak adanya hubungan dengan $\mathrm{Tb}$ paru, bila di hubungkan dengan jenis kelamin responden , jenis kelamin perempuan 26 atau 65\%, berumur 31-40 tahun dan perkerjaan sebagian ibu rumah 
tangga keberadaan ibu-ibu muda di sini menurut peneliti masih kurang untuk menjaga kebersihan terutama membersihkan WC sehingga menimbulkan bau, bila keadaan ini berlanjut terus menerus akan mengudang keberadaan vektor penyakit dan merupakan risiko untuk terkenadiare.

Tabel 6. Distribusi Keadaan suasana rumah dengan TB Paru di Rungan Poli Paru terpadu Juni - Agustus 2017

\begin{tabular}{llrlrrr}
\hline No & $\begin{array}{c}\text { Suasana } \\
\text { rumah TG }\end{array}$ & $\begin{array}{c}\text { Resiko } \\
\text { PC }\end{array}$ & TB paru & Total & P.Value & OR 95\% Ci \\
\hline 1. & Baik & $10(66,7 \%)$ & $5(33,3 \%)$ & 15 & 1.02 & $0,10($ CL2,66-18,96) \\
\hline 2. & Tidak baik & $13(52, \%)$ & $12(48 \%)$ & 25 & &
\end{tabular}

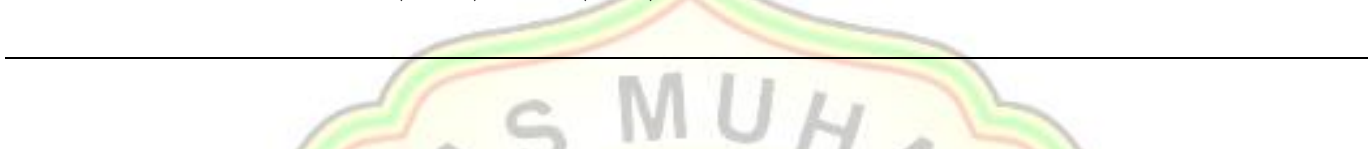

Keadaan resiko Perceraian tidak ada hubungan dengan Tb paru karena dari hasil uji statistik chisquare dengan continuity correction diperoleh nilai $\mathrm{p}=(1,02)>\alpha(0,05)$, dengan demikian $\mathrm{p}$ value lebih besar dari alpha, berarti tidak ada berpedaan yang terkena $\mathrm{Tb}$ paru dengan yang ada resiko perceraian maupun yang tidak ada resiko peceraian ,Namun secara presentase responden pada kondisi suasana rumah tanggah baik 10 (66,7\%) dan terkena Tb paru 5 (33,3\%) Pada hasil diatas OR yaitu 1,02, (95\% Ci:2,66-18,96), ini berarti ada suasana rumah tanggah tidak baik mempunyai peluang 0,10 untuk terkena dibandingkan dengan baik Menurut peneliti tidak adanya hubungan resiko peceraian dengan Tb paru dari hasil diatas dapat ketahui bahwa keadaan responden di sebabkan ada faktor lain belum peneliti ketahui hal ini merupakan kecendrungan untuk risiko terkena Tb Paru ini bisa saja terjadi. Keberadaan dari suasana rumah tangga yang kurang baik tidak sehat dari kurangnya pemahaman dari kedua pasangan beresiko untuk melakukan peceraian. Faktor lain yang menjadikan tidak ada hubungan resiko peceraian dengan $\mathrm{Tb}$ paru, pemahaman dari susanan rumah yang sehat daya responden di mana umur responden berusia $31-40$ th ; 34,37\% ini memungkinkan pemikiran yang kuat.Menurut pendapat Neely, 2005 keadaan lingkungan rumah atau suasana yang tidak dapat membuat sehat atau baik, hal ini merupakan risiko peceraian.

\section{KESIMPULAN DAN SARAN}

\section{Kesimpulan}

Berdasarkan hasil Penelitia dan pembasaan tentang Kajian analisi hubungan kondisi Fisik rumah resiko Perceraian terhadap Penderita Tb Paru di runagn Perawatan Tb Paru terpadu RSUD Arifin achmad Pekanbaru Dapat di simpulkan :Terdapat nya hubungan antra ventelasi dengan $\mathrm{Tb}$ paru, karena dari hasil uji statistik chi-square dengan continuity correction diperoleh nilai $\mathrm{p}=(0,001)<\alpha=(0,05)$ Luas ventilasi dapat menyebabkan kejadian $\mathrm{Tb}$ paru dimana luas ventilasi $<15 \%$ lebih besar risikonya jika dibandingkan dengan $\geq 15 \%$. Suhu ruangan dapat menyebabkan kejadian $\mathrm{Tb}$ paru dimana suhu ruangan $<18^{\circ} \mathrm{C}$ lebih besar risikonya jika dibandingkan dengan $\geq$ $18^{\circ} \mathrm{C}$.

Saran 
Pada akhir penelitian ini, berdasarkan hasil yang diperoleh maka beberapa saran yang bisa diberikan, yaitu bagi rumah sakit /dinas kesehtan $\mathrm{n}$ dan stakeholder terkait dapat melakukan promosi sebagai tindakan pencegahan terutama bagi masyarakat yang mempunyai faktor risiko yang tinggi, dengan cara memberi penyuluhan kepada masyarakat tentang persyaratan rumah sehat. Bagi masyarakat dapat menciptakan lingkungan rumah yang memenuhi persyaratan seperti luas ventilasi yang lebih dari $15 \%$ dan suhu ruangan diatur pada $18-30^{\circ} \mathrm{C}$ karena halhal ini menjadi faktor penghambat kejadian Tb paru. Dan saling memahami antara kedua pasangan untuk menghindari resiko peceraian dan kedua pasangan yang menderita $\mathrm{Tb}$ paru perlu terus di berikan bimbingan dan pemahaman.

\section{DAFTAR PUSTAKA}

Adi Rukminto isbandi,2003 Pemberdayaan,pengembangan masyarakat dan intervensi komunikasi Penerbit Fakultas Eonomi UI

Anonim. 1999. Keputusan Menteri Kesehatan Republik Indonesia No.829/MenKes/SK/VII/1999 tentang Persyaratan Kesehatan Perumahan. Departemen Kesehatan RI. Jakarta

Anonim. 2002. Komunikasi Interpersonal Antara Petugas Kesehatan Dengan Penderita Tuberkulosis. Direktorat Jenderal PPM dan PL Departemen Kesehatan RI. Jakarta

Anonim. 2004. Pedoman Nasional Penanggulangan Tuberkulosis. Depertemen Kesehatan RI. Jakarta

Anonim. 2005. Survei Prevalensi Tuberkulosis di Indonesia. Departemen Kesehatan RI. Jakarta

Anonim. 2008. Riset Kesehatan Dasar tahun 2007. Departemen Kesehatan RI, Jakarta

Buchari alma,2007Pengatar statistic,pendidikan,social, ekonomi, komunikasi, dan bisnis,Alfabeta Bandung

Mark Edberg,2007 Kesehatan masyarakat Teori social dan perilaku Penerbit Buku kedokteran EGC Jakarta.

Notoatmodjo, S 2007 Pendidikan dan Perilaku Kesehatan, Rineka Cipta Jakarta

Notoatmodjo S.2003 Ilmu kesehatan Masyarakatan prinsip-prinsip dasar, Rineka Cipta Jakarta

Sumijatun, 2011 Membudayakan Etika dalam praktek Keperawatan ,Salemba Medika.

Repulika co.id 2014Riau Peringkat 10 Penduduk Terbanyak Indonesi

http://www.republika.co.id/berita/nasional/daerah/14/01/29/n05z9c-riau-peringkat-10- penduduk-terbanyakindonesia di kunjungi 5 Febuari 2015

Sumijatun,2011 Membudayakan Etika dalam praktek Keperawatan ,Salemba Medika.

Wahit, 2007 Promosi Kesehatan sebuah pengantar proses pembelajaran mengajar dalam pendidikan,Graha Ilmu Jakarta.

Gunarsa, S. D. (1999). Psikologiuntuk Keluarga.Cetakan ke 13.Jakarta: Gunung Agung Mulia.

Hurlock,EB(1994). Psikologi Perkembangan, SuatuPendekatan Sepanjang Rentang Kehidupan. Jakarta

:Erlangga. 